\title{
Biological Activities of Some Essential Oils from Plants of Mexico
}

\author{
Estanislao Gómez CC ${ }^{1}$, Pérez Ishiwara DG ${ }^{2}$ and Gómez García MC $^{2 *}$ \\ ${ }^{1}$ Departamento de Morfología, Escuela Nacional de Ciencias Biológicas, Instituto Politécnico Nacional. Unidad Profesional Lázaro Cárdenas, \\ prolongación de Carpio y Plan de Ayala s/n, Col. Santo Tomás C.P. 11340, Delg, Miguel Hidalgo, Ciudad de México
}

${ }^{2}$ Programa de Maestría en Ciencias en Biomedicina Molecular y Doctorado en Biotecnología, Escuela Nacional de Medicina y Homeopatía, Instituto Politécnico Nacional, Guillermo Massieu Helguera No. 239, Fracc. La Escalera, Ticomán, Delg. Gustavo A. Madero, México, C.P. 07320, D. F., México

Submission: February 02, 2017; Published: September 08, 2017

*Corresponding author: Gómez García MC, María del Consuelo Gómez García, Programa de Maestría en Ciencias en Biomedicina Molecular y Doctorado en Biotecnología, Escuela Nacional de Medicina y Homeopatía, Instituto Politécnico Nacional, Guillermo Massieu Helguera No 239, Fracc La Escalera, Ticomán, Delg Gustavo A Madero, México, Fax: (+46) 57296000 ext 55534; Tel: (+46)57 2960 00; Ext 55541;

Email: cgomezg@ipn.mx; consuelogg22@yahoo.com.mx

\section{Abstract}

México is a country with a valuable source of flora including more than 6000 medicinal plants. Those diverse floral compositions provide a vast number of natural products beneficial for human population due to the plants are a potential source of drug discovery against different ailments. Essential oils are complex mixtures of secondary metabolites. Their mainly components are monoterpenes that are responsible for their biological effects. However, their composition depends on different environmental factors. Actually, some scientifical research has demonstrated their biological activity: antimicrobial, antioxidant, anti-inflammatory and anticancer. This review describes the effect of some essential oils isolated from Mexican plants such as oregano, lavander, laurel, Rosemary and arantho between others. We described the extraction method, the phytochemical composition, mainly the major compounds and their potential effects against fungi, bacteria and cancer cells.

Keywords: Essential oil; Biological activity; Antimicrobial antioxidant; Anticancer

Abbreviations: Essential oil (EOs); Gas chromatography/Mass spectrometry (GC/MS); Minimum inhibitory concentration (MIC); Effective concentration (EC50)

\section{Introduction}

Essential oils (EOs) are complex mixtures of volatile compounds produced by living organisms and isolated by physical means only (pressing and distillation) from a whole plant or plant organs of known taxonomic origin [1]. They are volatile liquid, insoluble in water, highly soluble in alcohol, ether, vegetable and minerals oils. They can be characterized by their main volatile components [2]. These volatile compounds belong to various chemical classes: alcohols, ethers or oxides, aldehydes, ketones, esters, amines, amides, phenols, heterocycles, and mainly the terpenes.

The composition and the effect of the EOs depend mainly on the harvesting season, extraction method and geographical sources $[3,4]$. Many of these volatile substances have diverse ecological functions. They can act as internal messengers, or intermediary metabolic products, as defensive substances against herbivores or as volatile compounds directing not only natural enemies to these herbivores but also attracting pollinating insects to their host [5].
The proportion of the volatile components varies from one EO to another, even within species, providing to each species different toxic and medicinal properties [6]. In recent years, different groups have been studied the efficacy of EOs and their chemical constituents as source of new bioactive natural products [7]. Initially, EOs was considered as waste material of plant metabolism; however, currently their biological importance has been recognized for their therapeutic properties [8]. EOs is important in medicine for their pleasant flavor, palliative effect to the pain and their low toxicity [9]. Also, scientific research over the past two decades has demonstrated various biological activities of EOs including anticancer, antiviral, analgesic, antioxidant, antibacterial and antifungal activities, as well as their ability to facilitate the passage of active molecules through the skin [10].

México present a high diversity of flora and more than 6000 medicinal plant species are used for the treatment of various diseases [11]. Interestingly, the EO of different Mexican medicinal 
plants have been isolated and tested because of their biological activities, such as antioxidant, antimicrobial, fungicidal and anticancer effect. Some species of plants are Lippia graveolens L. berlandieri schauer, Rosmarinus officinalis, Laurus nobilis, Lavandula $\mathrm{x}$ intermedia, Thymus vulgaris, between others.

\section{Antibacterial Activity}

The EO of Lippia berlandieri Shauer has been isolated from the aereal parts by conventional steam distillation process to evaluate its antioxidant activity by DPPH (2-2'-diphenyl1-picrylhydrazyl) method. Also, the ethyl acetate extract was evaluated. The essential oil showed a low radical scavenging activity, while the extract exhibited this activity at higher concentrations $(100 \mu \mathrm{g} / \mathrm{ml})[12]$.

Also, oregano and its derivatives have been studied for their antimicrobials effects; this effectiveness is attributed to two compounds in its EO, carvacrol and thymol that inhibit pathogenic microorganisms [13,14]. Paredes-Aguilar [13] assessed the antimicrobial effect of $L$. berlandieri Schauer and its EO against Vibrio alginolyticus V. cholerae no-01, Vibrio mimicus, Vibrio parahaemolyticus and Vibrio vulnificus. The plant was collected from Salaices, Chihuahua, Mexico where they used the leaves to prepared EO. The effect was determined by the minimal inhibitory concentration and minimal bactericidal concentration (MIC and MBC), the results showed a favorable antimicrobial effect of oregano on all five species of Vibrio, which did not show significant differences for MIC and MBC values, at concentrations of 1.5 to $2.5 \%$ of oregano, and of $100-200 \mathrm{mg} / \mathrm{L}$ of the EO.

Ortega-Nieblas [15] analyzed the antimicrobial activity of the EO of Lippia palmeri S. Wats leaves. The plants were collected of two localities (Álamos and Puerto del Orégano) in the State of Sonora, México and the EOs presented almost 60 constituents such as monoterpenes, sesquiterpenes and phenolics. The antimicrobial activity was against four Gram-positive and six Gram-negative bacteria. However, both EOs showed the strongest activity against Escherichia coli 0157:H7 and Staphylococcus aureus using different dilutions of the EO (1:1, 1:5, and 1:10).

The EO of lavender (L. x intermedia), rosemary (R. officinalis) and laurel (L. nobilis) were obtained from plants cultivated in Dolores Hidalgo, Mexico and were analyzed by GC/MS. The analysis showed a 3-and 2-fold increase in camphor and linalool concentration in rosemary and laurel. Also, their antibacterial activity was assessed on strains of Gram-positive (Mycobacterium smegmatis) and Gram-negative (E. coli) bacteria using the agar disc diffusion method, the results showed a better antibacterial activity of lavender and laurel EO $(5 \mu \mathrm{l})$ against $M$. smegmatis [16].

The essential oil of the aerial parts of Lantana achyranthifolia Desf. (Verbenaceae) were collected in Zapotitlan de las Salinas, Puebla. The EO was studied by GC and GC-MS. The major components found were carvacrol, 1, 8-cineole, isocaryophyllene, bisabolene and -bisabolol. The oil exhibited antibacterial activity against fourteen Gram-positive and Gram-negative bacteria such as V. cholerae, Shigella boydii, S. aureus, S. epidermidis, Bacilus subtilis and Sarcina lutea; and the MIC were between 0.25 and $1 \mathrm{mg} / \mathrm{ml}$ [17].

\section{Antifungal Activity}

In a study of Guerra [18], et al, 2015, the antibacterial and antioxidant effect of EO of some species such as T. vulgaris, $R$. officinalis and Origanum majorana from northeastern México were evaluated. The results showed that the EOs of T. vulgaris and 0 . majorana inhibited the growth of Trychophytum rubrum, $T$. tonsurans, T. mentagrophyte, between others; and the minimum inhibitory concentration (MIC) values were between 62.5 and $500 \mu \mathrm{g} / \mathrm{mL}$; however, the antioxidant activity was low, with effective concentration (EC50) values $>250 \mu \mathrm{g} / \mathrm{mL}$.

The EO of the leaves of T. vulgaris $L$. was collected in Guadalajara, Jalisco, Mexico. It was chemically analyzed by GC/MS and evaluated for its fungicidal activity. The main constituents reported were borneol (28.4\%), thymol (16.6\%), carvacrol methyl ether (9.6\%), camphene (6.9\%), $\alpha$-humulene $(6.4 \%)$ and carvacrol (5.0\%). The fungicidal activity showed an inhibitory effect against Alternaria citri using a concentration of 1000 ppm [19].

\section{Anticancer activity}

Estanislao [20] evaluated the antitumoral effect of the leaves of the EO Decatropis bicolor plant from The Cardonal, Hidalgo, and Mexico. The results demonstrated that the EO induced a cytotoxic effect on MDA-MB-231 breast cancer cell line with an IC50 of $53.8 \mu \mathrm{g} / \mathrm{ml}$. Also, the EO induced an apoptotic cell death with activation of the intrinsic pathway, DNA fragmentation and morphological changes.

In the same way, Torres [21], evaluated the EOs of fifty plants belonging to the Myrtaceae, Schisandraceae, Lauraceae, Asteraceae and Pinacea Family, between others. They analyzed the anti-inflammatory and anticancer activity of the EOs. The results showed that five and seven EOs produced cytotoxicity in the human pancreatic cancer cell lines MIAPaCa-2 and BxCP-3, respectively, when using $100 \mu \mathrm{g} / \mathrm{ml}$. Also, some EOs induced the activation of caspases corresponding to apoptotic cell death.

\section{Discussion}

Despite their rich and complex composition, the use of EOs remains wide and limited to the cosmetics and perfumery. It is important to develop a better understanding of their chemistry and the biological properties and their individual components for new and valuable applications in human health, agriculture, and the environment. EOs could be exploited as effective alternatives or complements to synthetic compounds of the chemical industry, without inducing the same secondary effects [22].

Monoterpenes are a class of volatile organic compounds whose, with others, are responsible for the main medicinal and olfactory properties of EOs. The proportion of these compounds 
usually determines the quality of EOs used as perfumery standards (high content of linalool and linalyl acetate combined with trace amount of camphor) or as medicinal standards (high contents of bioactive monoterpenes) [16].

Since ancient times traditional Mexican medicine has used a wide variety of plants to treat different disorders, so the studied of the EOs is important to provided information about its biological effects such as antibacterial, antioxidant and anticancer, between other. Antibacterial activity of EOs and their constituents have been showed the hydrophobicity of the EOs, allows them to partition into lipids of the cell membrane of bacteria, disrupting the structure, and making it more permeable. This can then cause leakage of ions and other cellular molecules [23-25].

The antioxidant potential of an EO depends on its composition, the phenolics and secondary metabolites with conjugated double bonds usually show substantial antioxidative properties [26]. EOs with scavenging capacity of free radicals play an important role in some disease prevention, such as brain dysfunction, cancer, heart disease and immune system decline [27].

Finally, anticancer activities of EOs have been intensively explored in recent years due to the necessity to obtain new drugs or complementary treatments for cancer. Various mechanisms involved in cancer treatment are activation of detoxification enzymes, modulation of DNA repair signaling, antimetastasis and antiangiogenesis. Also, multiple pathways are involved in the antiproliferative activity produced by EOs [27].

\section{Conclusion}

Many plant species possess potential for use as a beneficial therapeutic remedy with multiple pharmacological actions with the advantage to not induce adverse reactions in contrast to the synthetic drugs. Particularly the EOs possess multiple compounds that present a great potential in the field of medicine since they effectively destroy different type of cells and pathogens. In this review we summarized the performed investigations about EOs of Mexican medicinal plants where antibacterial, antifungal, antioxidant and anticancer activities were observed. Nevertheless further analyses needs to be undertaken in order to identify the compound or compounds that induces those activities as well as to carry out pharmacological and clinical studies to establish scientific basis for the future development of new drugs.

\section{References}

1. Baser KHC, Buchbauer G (2010) Handbook of Essential Oils, Science, Technology, and applications. CRC Prress, Taylor \& Francis Group, USA, p. 994.

2. Arana-Sánchez A, Estarrón-Espinosa M, Obledo-Vázquez EN, PadillaCamberos E, Silva-Vázquez, et al. (2010) Antimicrobial and antioxidant activities of Mexican oregano essential oils (Lippia graveolens H B K) with different composition when microencapsulated in b-cyclodextrin. Lett Appl Microbiol 50(6): 585-590.
3. Burt S (2004) Essential oils: Their antibacterial properties and potential applications in foods. Int J Food Microbiol 94(3): 223-253.

4. Santoyo S, Caver S, Jaime L, Ibáñez E, Señorans FJ, et al. (2006) Supercritical carbon dioxide extraction of compounds with antimicrobial activity from Origanum vulgare L: Determination of optimal extraction parameters. J Food Prot 69(2): 369-375.

5. Harrewijn P, Van Oosten AM, Piron PGM (2001) Natural Terpenoids as Messengers. Kluwer Academic Publishers, Dordrecht, Netherlands.

6. Kaloustian J, Abou L, Mikail C, Amiot MJ, Portugal H (2005) Southern French thyme oils: chromatographic study of chemotypes. J Sci Food Agric 85(14): 2437-2444.

7. Sobral MV, Xavier AL, Lima TC, Pergentino de Sousa D (2014) Antitumor Activity of Monoterpenes Found in Essential Oils. The Scientific World Journal 2014(2014): 1-35.

8. Edris A (2007) Pharmaceutical and Therapeutic Potentials of Essential Oils and Their Individual Volatile Constituents. Phytother Res 21(4): 308-323.

9. Soto MEA, Moreno RJF, Estarrón EM, García FJA, Obledo VEN (2006) Chemical composition and fungicidal activity of the essential oil of Thymus vulgaris against Alternaria citrie. Gnosis 4: 16.

10. Bakkali F, Averbeck S, Averbeck D, Idaomar M (2008) Biological effects of essential oils A review. Food Chem Toxicol 46(2): 446-475.

11. Lautié E, Quintero R, Fliniaux MA, Villarreal ML (2008) Selection methodology with scoring system: application to Mexican plants producing podophyllotoxin related lignans. J Ethnopharmacol 120(3): 402-412.

12. Rocha GNE, Gallegos IJA, González LRF, Ramos GM, Rodríguez MME, et al. (2007) Antioxidant effect of oregano (Lippia berlandieri v. Shauer) essential oil and mother liquors. Food Chem 102(1): 330-335.

13. Paredes AMC, Gaste'lum FMG, Silva VR, Neva'rez MGV (2007) Efecto antimicrobiano del orégano mexicano (Lippia berlandieri Shauer) sobre cinco especies del género Vibrio. Rev Fitotec Mex 30(3): 261-267.

14. Aligiannis N, Kalpoutzakis E, Mitaku S, Chinou IB (2001) Composition and antimicrobial activity of the essential oils of two Origanum species. J Agric Food Chem 49(9): 4168-4170.

15. Ortega-Nieblas MM, Robles-Burgueño MR, Acedo-Félix E, GonzálezLeón A, Morales-Trejo A, et al. (2011) Chemical composition and antimicrobial activity of oregano (Lippia palmeri S. WATS) essential oil. Rev Fitotec Mex 34(1): 11-17.

16. Rodriguez FC, Pennec A, Nugier-Chauvin C, Daniellou R, HerreraEstrella L, et al. (2014) Chemical Composition and Antibacterial Activity of Essential Oils Extracted from Plants Cultivated in Mexico. J Mex Chem Soc 58(4): 452-455.

17. Hernández T, Canalesa M, Avilaa JG, García AM, Martínez A, et al. (2005) Composition and antibacterial activity of essential oil of Lantana achyranthifolia Desf. (Verbenaceae). J Ethnopharmacol 96(3): 551-554.

18. Guerra B L, Alvarez-Román R, Salazar-Aranda R, Torres-Cirio A, RivasGalindo VM, et al. (2015) Antimicrobial and antioxidant activities and chemical characterization of essential oils of Thymus vulgaris, Rosmarinus officinalis, and Origanum majorana from northeastern México. Pak J Pharm Sci 28(1 Suppl): 363-369.

19. Soto MEA, Moreno RJF, Estarrón EM, García FJA, Obledo VEN (2006) Chemical composition and fungicidal activity of the essential oil of Thymus vulgaris against Alternaria citrie. Gnosis 4: 16.

20. Estanislao GCC, Aquino CA, Pérez IDG, San Martín ME, Morales LJ, et al. (2016) Decatropis bicolor (Zucc.) Radlk essential oil induces apoptosis of the MDA-MB-231 breast cancer cell line. BMC Complement Altern Med 5: 16-266. 
21. Torres SA, Hoheisel J, Youns M, Wink M (2011) Anti-inflammatory and anti-cancer activities of essential oils and their biological constituents. Int J Clin Pharmacol Ther 49(1): 93-95.

22. Dhifi W, Bellili S, Jazi S, Bahloul N, MnifW (2016) Essential oil's chemical characterization and investigation of some biological activities: a critical review. Medicines 3(4): 25.

23. Lambert RJW, Skandamis PN, Coote P, Nychas GJE (2001) A study of the minimum inhibitory concentration and mode of action of oregano essential oil, thymol and carvacrol. J Appl Microbiol 91(3): 453-462.

24. Cox SD, Mann CM, Markham JL, Bell HC, Gustafson JE, et al. (2000) The mode of antimicrobial action of essential oil of Melaleuca alternifola (tea tree oil). J Appl Microbiol 88(1): 170-175.
25. Ultee A, Bennink MHJ, Moezelaar R (2002) The phenolic hydroxyl group of carvacrol is essential for action against the food-borne pathogen Bacillus cereus. Appl Environ Microbiol 68(4): 1561-1568.

26. Koh KJ, Pearce AL, Marshman G, Finlay-Jones JJ, Hart PH (2002) Tea tree oil reduces histamine-induced skin inflammation. Br J Dermatol 147(6): 1212-1217.

27. Gautam N, Mantha AK, Mittal S (2014) Essential oils and their constituents as anticancer agents: a mechanistic View. Biomed Research International 2014(2014): 1-23.

\section{Your next submission with Juniper Publishers will reach you the below assets}

- Quality Editorial service

- Swift Peer Review

- Reprints availability

- E-prints Service

- Manuscript Podcast for convenient understanding

- Global attainment for your research

- Manuscript accessibility in different formats

(Pdf, E-pub, Full Text, Audio)

- Unceasing customer service

Track the below URL for one-step submission https://juniperpublishers.com/online-submission.php 